\title{
Establishing a middle ground for public and community broadcasting in Indonesia: An action research project
}

\author{
EFFENDI GAZALI, LEEN D'HAENENS, ED HOLLANDER, \\ VICTOR MENAYANG, and DEDY NUR HIDAYAT
}

\section{Abstract}

The Reform movement that ended Suharto's 32 years of authoritarian rule brought significant changes to Indonesia. It liberated the media, the market, and civil society from state repression. But at the same time, the end of authoritarian rule brought about a vast shift to a libertarian market orientation, especially in the field of mass media. Against this background, a consortium of NGOs, academics in the field of communication and politicians have been trying to establish a 'middle ground' for discussions and legal implementation of public and community broadcasting in Indonesia. This paper discusses the outcomes of focus group discussions held in an effort to establish a platform for decentralization of broadcasting in Indonesia. These groups consisted of local people and spokespersons of constituent groups in ten provinces throughout Indonesia. The public hearings showed how constituent groups in society can and should be involved in media policy negotiations which so far predominantly took place at the national level only.

Keywords: Public broadcasting, community broadcasting, Indonesia, action research

\section{Situation in Indonesia}

There is little doubt that the media system during the New Order regime was authoritarian. The Suharto regime put into place a systematic and comprehensive strategy to ensure that the mass media functioned as control instruments of power. Hidayat, Gazali, Suwardi, and Ishadi (2000: 6) summarize the main ingredients of Suharto approach as follows:

1. Preventive and corrective control of the ownership of the media institutions, through the issuance of licenses mainly on the basis of political criteria; 
2. Control of individual and professional practitioners (journalists) through selection and regulation mechanisms, such as the requirement for journalists to join the one and only journalist organization allowed at the time, the obligation for chief editors to attend courses on state ideology (Pancasila or 'Five Pillars'), which is in fact a kind of indoctrination process;

3. Control of the appointment of individuals on certain positions in government-owned media;

4. Control of news texts (both content and format) through various mechanisms;

5. Control of resources, for example, through a monopoly on paper distribution;

6. Control of access to the press, for example, by forbidding press coverage of opposition leaders.

This strategy effectively turned the Indonesian media system into a system that was centralistic, based on cronyism, and directed from Jakarta. The implementation of the strategy was more apparent in the TV broadcasting scene through the domination of Televisi Republik Indonesia (TVRI), established in 1962 as the only TV station until 1987 and run by the government under the Ministry of Information. Afterwards, television licenses were issued only to the presidential family - known as the Cendana family - and their political and business cronies.

In 1987 Rajawali Citra Televisi Indonesia (RCTI) became the first commercial TV station to be allowed to operate in Indonesia, 25 years after TVRI started its operation. The station could only freely broadcast (without a decoder) in 1989. Suharto's son, Bambang Trihatmodjo, was the president of RCTI as well as the chair of its board of directors. Bambang's company, Bimantara Citra, also held the majority of the shares, followed by Rajawali Wirabhakti Utama, a company led by Peter Sondakh, a close friend of Bambang. By the end of 1989, the second commercial station, Surya Citra Televisi (SCTV) was licensed to go on the air. Infact, SCTV went on the air in 1990. SCTV used to be regarded as RCTI's little sibling, although it is now independent. SCTV was in the hands of Sudwikatmono, Suharto's stepbrother, and businessman Henri Pribadi.

In August 1990, a third commercial station was granted a license. Since there were already two generalist commercial stations, this third one was allowed only because it focused on education. Indonesian Educational TV (Televisi Pendidikan Indonesia or TPI) was in the hands of Siti Hardiyanti Rukmana, Suharto's eldest daughter. TPI was to become just another commercial station except for a few instructional educational programs (based on text books) during the morning hours. 
In January 1993, the fourth commercial station, Cakrawala Andalas Televisi (ANteve) was granted a license by the Ministry of Information. ANteve was in the hands of the Bakrie Brothers group, belonging to one of the most important entrepreneurial families in Indonesia, and Agung Laksono, the then head of the central committee board of the ruling party, Golongan Karya. Indonesia's fifth commercial broadcaster and the last one during the Suharto era was Indosiar Visual Mandiri (IVM). As early as 1991, IVM was granted a license, but it was not until January 1995 that the station went on the air. IVM was in the hands of the Salim group, one of the biggest and most powerful conglomerates in Indonesia led by Lim Sioe Liong, a close friend of Suharto (for a more detailed account of the original set of TV stations in Indonesia, see d'Haenens, Gazali, and Verelst 1999: 127-152 and d'Haenens, Verelst, and Gazali 2000: 197-232).

While the process of selecting these license holders was far from transparent, the procedure for granting commercial licenses itself was interesting for at least four reasons. First, the policy of opening up to commercial stations could be seen as a response calculated by the government to the ever-increasing pressure from transnational broadcasting. In light of the 'open-sky' policy put in place by the Ministry of Information in 1984, the Indonesian government had bought into the idea that its best defense against transnational television was to improve the competitiveness of domestic television industries (Chan and Ma, 1996: 48). Secondly, among the five original commercial TV stations, two were based outside Jakarta. SCTV was broadcasting in Surabaya, the capital city of East Java and ANTeve was located in Lampung, Sumatra. In fact, they were forced to relocate to Jakarta within the second or third operational year, the main reason being that the advertisers were mostly concentrated in Jakarta. Thirdly, even in the beginning of its operational years, ANteve rebroadcast 6.5 hours of MTV programs every day. This was of course in violation of the government strategy of granting domestic commercial licenses that considered the production of national programs as a defense against international broadcasters. And finally, IVMthe station that later became one of the strongest TV players in the TV industry seen as a model of efficiency by other stations, chose to follow Television Broadcasts Limited (TVB), Hongkong, as its model of efficient programming and production. IVM even contracted some professionals from TVB when it was establishing its facilities and infrastructure. This outsourcing to TVB only ended when other media reported and raised the issue of hiring (too) many foreign employees.

After the fall of Suharto, President Habibie appointed Mohammad Yunus Yosfiah as the Minister of Information. For the first time the ministry conducted a bidding contest to obtain licenses for commercial TV broadcasting. Ten corporations submitted applications to the five 
available national licenses. Based on the licenses issued on 25 October 1999, the winning stations were the following: PT Transformasi Televisi Indonesia (operating Trans TV), PT Metro Televisi Indonesia (Metro TV), PT Pasar Raya TV (Lativi), PT Dipa Visi Nusantara, and PT Global TV (Global TV). All these new stations had to start their activities at least two years after their license was issued.

Again, there were a few things worth noticing in this licensing process. First, the lack of transparency was immediately criticized by the other applicants. Secondly, the license could be transferred to other corporations even though the latter was granted on the explicit condition that certain people would run the station. In this case, PT Dipa Visi Nusantara transferred its license to the Kompas Group that would later operate TV 7. And finally, just like the previous five TV licensees, the new five Jakarta-based stations all held a national broadcasting license.

The liquidation of the Ministry of Information by President Abdurrahman Wahid on 27 October 1999 put the broadcasting industry in a legal vacuum. No longer was there an executor of the effective Broadcasting Laws 24 of 1997. The state broadcasting enterprises, TVRI and Radio Republik Indonesia (RRI), were specifically affected by the eradication of this Ministry since they were structurally dependent on the Ministry of Information. In 2000, both TVRI and RRI were transformed into public broadcasting organizations through Government Regulations 36 (for TVRI) and 37 (for RRI).

The radio landscape has always been different from the television industry in Indonesia. RRI was established on 11 September 1945 and already since 1968 commercial radio stations were allowed in Jakarta. Moreover, while the commercial TV stations were all based in Jakarta until 2001, local commercial radio stations had been blooming in many cities and regions since 1970. Both commercial TV and radio stations, however, shared the obligation to relay the main news programs of their state counterparts. Commercial stations were not allowed to produce their own news programming and had to resort to package news items into something like features or soft news (see also Hidayat et al., 2000: 165-203). While the TV stations were obliged to relay two news programs of TVRI, the situation was worse for radio stations because they had to relay RRI news up to 18 times a day. The relay obligation for TV was cancelled in 1997, the one for radio was lifted in 1998. In 1999 the regional autonomy law (No. 22, 1999) was issued. This opened up opportunities for the development of local TV and radio stations. According to this law, regional governments are authorized to allocate radio frequencies. However, this is in conflict with another law about telecommunications stipulating that the authority to allocate frequencies lies solely with the Ministry of Telecommunications. Despite the legal ambi- 
guity, a few local TV and radio stations were established early, riding on the liberal spirit of the Reform Movement. It was interesting that the operators/owners of these new stations were unclear about the nature of their activity, whether it was commercial, public, or a community broadcasting institution. These three categories were later adopted officially as categories of broadcasting in the Broadcasting Bill proposed by the legislative body (Gazali 2002: 23-24). In its response on May 2001, the executive government rejected some core concepts within the proposed draft. One of the most absurd arguments put forward by the government was the rejection of the term 'broadcast institution' claiming it to sound too state-like and proposing the use of the term 'broadcast operators' instead. A more significant issue was the government's refusal of the existence of public broadcasting and community broadcasting. It recognized only state broadcasting operator versus private broadcasting operators. Apparently, the executive government failed to see that their concepts only dealt with the owner or founder of stations and did not address the characteristics of broadcasting. The latter can only be captured by the terms commercial, public, and/or community broadcasting.

Some of the most recent developments related to the broadcasting world and civil society in Indonesia should also be considered. First, the amendment to the 1945 Constitution has been seen by media people as conducive to the existence of local radio and TV stations (see, for example, Suryokusumo in Gazali 2002: 133-134). Specifically, the amendment to Article 28 that led to Article 28F states: "Everyone has the right to communicate and to obtain information to improve one's welfare and that of the social environment, as well as the right to seek, to obtain, to own, to store, to process, and to convey information using any available channel". Article 28I states: "The cultural identity and the rights of the indigenous people should be respected in accordance with the advancement of civilization." Secondly, the confusion about who has the authority to allocate frequencies in the region has led to the shutdown of two local TV stations. In addition, one transmitter of $J-T V$ (the station belonged to the large newspaper chain, the Jawa Pos group) in Surabaya was seized. The new local radios are facing similar problems. In East Java, there are raids on these radio stations conducted by special telecommunications police forces supported by the provincial branch of the Association of Private Commercial Radio Stations (PRSSNI).

In short, the television landscape in Indonesia has never allowed an opportunity for the development of local television. The main reason for this is that the Broadcasting Law has never granted legal status to local television. Worse even, community and public television have never really been conceived as an alternative to the state and commercial televi- 
sion. In the case of radio, although local commercial radio has long existed, other forms of radio have not been fully explored by the local communities. However, Indonesia is now more than ever in a specific historical transition, offering new opportunities for public and community TV and radio stations. Hidayat (in Gazali, 2002: 4-18) argued that in the Indonesian context at least three reasons can be considered for why it is not desirable to let the shift in broadcasting - from a government propaganda instrument to a system controlled by the market only - take place.

First, the logic of capital accumulation will dominate in determining what and whom should be excluded from the broadcasting context. Issues to be addressed will eventually be determined by the extent to which they do not interfere with the interest of capital expansion. Moreover, the broadcast should implicitly convey the ideological values that portray competition and the unlimited rights to capital accumulation as natural and normal. In such a context, local traditional arts can easily be considered secondary to the popular art forms that are fostered by the market. Secondly, the principle of capital accumulation will eventually increase the cost of broadcasting making it only accessible to certain groups and individuals. This would almost certainly lead to the exclusion of issues of interest to those without access to the use of broadcasting media. Thirdly, the principles and logic of the market will exclude broadcasting institutions that do not comply with the pressure from advertisers. Alternative media that voice out public interests or position themselves as fora for public dialogue - without taking into account 'consumer taste' - would have a very low survival rate. A potentially negative effect of the market concentration is the homogenization of media content. In the end, this would resemble the state repression of the New Order regime when - through what was called national culture - the definition of social reality from the government was the only valid and logical one (see, among others, Sen and Hill, 1990).

Based on these assumptions, we argue that public and community broadcasting is a necessary alternative. However, only when the system sufficiently recognizes the supervisory and evaluative role of the public on broadcasting can public and community broadcasting become an effective alternative (Gazali, 2002: 52-56). Without such evaluation and supervision, this so-called alternative would only be another false choice, and public and community broadcasting institutions would turn into paternalistic bodies pretending to know what is good for the public and thus exclusively decide on what should be broadcast and what not (d'Haenens and Saeys, 2001: 120). 


\section{Research problem}

Against this background, a team of researchers of public and community broadcasting of the University of Indonesia aimed at studying the broadcasting situation and finding alternative solutions to the above-mentioned broadcasting problems. In an effort to guide its activities, the team asked the following questions:

1. What is the basic comprehension of the public broadcasting concept; what are the taken-for-granted assumptions about broadcasting and public broadcasting, and positioning of TVRI and RRI among the local key representatives?

2. After being introduced to concrete public broadcasting experiences in other societies, how does a wider audience comprising of local broadcasters and stakeholders clarify their perceptions of and felt needs about local public and community broadcasting?

3. How do local audiences see the need to maintain regional and local identities and cultures using the public and/or community broadcasting as the main forum, and how do they position the maintenance of regional and local identities in the context of national and global programming?

4. What would be the fora to sustain the discourses developed during the introduction of the public and community broadcasting concepts in order to ensure that community intervention into broadcasting can effectively be implemented as envisioned by the locals?

\section{Method}

This research is qualitative in that it relies mostly on observation and records of statements made in private and public meetings as well as in personal interviews. Short questionnaires were used in an effort to gauge the opinion of the larger public. In general, the research was meant as a combination of research and advocacy. The paradigm used was 'working with the people', as opposed to 'working for the people,' upon which the researchers from the outset have based their work on people participation in decision-making, in implementation, in sharing the benefits, and in evaluation (Cohen and Uphoff, 1980). It will then have to consider the implications of the development of people's capacity, equity, empowerment, and interdependence (Byrant and White, 1982: 15).

The team of the University of Indonesia started out with a set of preliminary 'pre-assessment' activities in ten cities in Indonesia, aimed at identifying basic comprehension of public broadcasting concepts, taken-for-granted assumptions about broadcasting and public broad- 
casting, and positioning of TVRI and RRI. At this stage, the researchers primarily interviewed key local leaders. The selection of the ten cities was done purposively with the intention of using each city as a hub where relevant parties from the surrounding areas would gather. Covering the whole span of Indonesia, the cities are: Medan, Padang, Bandung, Yogyakarta, Surabaya, Denpasar, Samarinda, Makassar, Manado, and Jayapura. It is worth noting that the participating communities can refer to the city community, the provincial community, or even to the regional communities.

The pre-assessments were conducted between July 2000 and January $2001^{1}$. The researchers met with representatives of the local communities, including NGO activists, academics, TVRI and RRI professionals, and commercial radio makers, regional government representatives, regional legislative members, social leaders, artists and cultural observers, religious leaders, business leaders, advertisers, and local media people.

During this first phase, the pre-assessment rounds, the researchers briefed the stakeholder representatives on issues relevant for public and local broadcasting. At this point, ideal characteristics of public and community broadcasting were offered and discussed, including: (1) mass media allowing public supervision and evaluation of programming; (2) mass media offering wider access to local people; (3) media offering wider and deeper coverage of relevant, local issues and problems; (4) media emphasizing more local arts and culture; (5) media that, while focusing on localities, also convey a shared interest in national identities in an effort to improve the audience's appreciation of the heterogeneity of Indonesia and at the same time to maintain national integration; and (6) media that, following examples of other countries, rely on public funding in many forms such as national budgets, regional budgets, license fees, advertisements, donations, underwritings, and others (for comparison, see Hollander, Stappers, and Jankowski 2002: 7-8 and 22-23).

A series of broad public forums, in the form of seminars, were organized as a response to this demand. These seminars constituted the second phase of the research/advocacy activities. The seminars were conducted in the same ten cities from April until August 2001. The participants came from the surrounding areas and were given an opportunity to discuss their perceptions and felt needs on local public and community broadcasting. Public broadcasting experiences in other countries, particularly the United States, Canada, and Germany, were presented. In total, 1345 participants (NGO people, local government staff, local parliament members, scholars, students, TVRI and RRI staff, cultural observers, artists, religious leaders, media people, and businesspeople) took part in the seminars. 
During the third phase, activities were facilitated to establish local groups in order to oversee public broadcasting development in each area. In the meantime, the advocacy and research team continued to hold several meetings in each city. The team also involved local stakeholders to produce radio and TV programs. A televized townhall meeting was chosen as the most plausible program to implement as a pilot project during the third phase. Collaborating with the local stakeholders, TVRI and RRI, the team managed to produce 309 local programs and to establish the first six initial local consultative forums (LCFs).

\section{Evidence so far}

\section{Pre-assessment activities}

During the pre-assessment rounds, it became clear that groups working with the locals at the grassroot level thought that a medium providing access to the common people was needed. They believed that the existing media had never been truly able to let the locals talk about their problems, in their own languages, adopting an approach relevant to them. For instance in Papua, the local NGOs and academics believed that the Jakarta- as well as the Jayapura-based mass media brought about topics that were not very helpful for the development of the community of Papua. Regarding television broadcasting, it was felt that what was shown were outsiders telling stories about themselves in the outside world. Even if these outsiders made a movie about Papua, it was usually about what they wanted to consume about Papua. This kind of program was felt to be entirely unsatisfactory for the people of Papua who are in need of information about, for instance, why they should plant banana trees in a certain area, how to benefit more of the banana production other than just selling bananas at a very low price, or letting them rot because the price offered at the market is too low.

The Papuan informants thought that the Papuan traditional performances on the Jakarta TV stations lacked authenticity. Furthermore, they suspected that Papuan traditional dances were only presented as background in state ceremonies to show that Papua is still part of Indonesia. Criticism on the dominance of programs of Javanese tradition also were voiced by artists and cultural observers in Bali and West Sumatra. In general, they shared the perception that these Java-based programs were causing alienation of the locals from their own culture. Artists and cultural observers in East Kalimantan and the surrounding areas complained about the lack of seriousness and professionalism of the local TVRI staff when producing cultural programs. The local TVRI often invited them only as a token gesture.

Another interesting phenomenon found by the advocacy and research team was that in North Sulawesi no substantial criticism was found 
about the lack of traditional performance programs, although the program composition at the Manado TVRI is quite similar to that of the other local TV stations. Subsequent interviews with NGO activists, artists, cultural observers and academics reveal that, in general, the Manadonese people are much more open to innovations and popular packaging of traditional performances. In addition, some people proudly remarked that the closing dance of the popular Jakarta TVRI program 'Dansa yo Dansa' (Come Along, Let's Dance) was a Manado-original Poco-poco dance. This remark was in sharp contrast to criticisms on the same show voiced by informants in the nine other cities complaining that the show imported culture unsuitable to the Indonesian cultural norms and values.

The religious leaders in all of the cities, except Manado, also voiced their concerns about the decreasing amount of religious programs on $\mathrm{TV}$, such as the teaching of the Quran reading and practice in life. They addressed their demand to local TVRI, not to Jakarta TV stations, which they considered already 'contaminated' by transnational programs conveying overseas cultures, such as Britney Spears with her sensual attire.

Local business communities seemed to be the least enthusiastic about the idea of public broadcasting. They were of the opinion that if the prime goal is to provide more access to local common people, the media cannot survive in the long run. Some business representatives in East Java and Bali, however, still saw the potential of these local stations promoting local products. The Bali business people, for instance, hoped that when local public broadcastings reached the hotels it would promote Bali, its traditional performances, and its cultural artifacts to a wider international audience.

Summarizing, the pre-assessment phase brought about the following findings:

(1) Each stakeholder group had its own set of reasons why to think an alternative broadcasting institution is needed. One common need was to put more emphasis on local people's aspirations;

(2) Although the informants acknowledged not to have a clearcut view of the concept of public broadcasting, they felt that the TVRI and RRI programming did not represent the principles of public broadcasting;

(3) When it came to the goal of maintaining local identities, culture, and traditional performances, they demanded a broadcasting system that would see them as active participants; they would like to see their own faces, and insisted on being portrayed as the host in their own home; 
(4) Most respondents suggested that it was important to hold a followup seminar involving a much larger group of stakeholders in order to talk about public broadcasting. They also suggested that the seminar should involve experts - some referred specifically to international experts who have acquired a great deal of experience with public broadcasting - to share information and concepts with the participants.

\section{Seminar series}

Following the recommendations of the pre-assessment rounds, the advocacy and research team then ran a series of two-day seminars in the above-mentioned ten cities. The seminars consisted of two parts: an introduction to public broadcasting concepts (by way of speakers' presentations) and a needs-assessment (involving all participants more actively). As indicated by the pre-assessment, the seminar series staged international speakers: Jim Byrd (Canada), David Brugger and Bob Ottenhoff (USA), and Eric Voght (Germany) who had been working with public radio and television broadcasting in their home countries. National and local speakers consisted of academics, NGO activists, media people, local government officials, local parliament members, and representatives of the central government (ministry of telecommunications). Only about 40 percent of national speakers came from Jakarta.

The seminars involved a total of 1345 participants in ten cities. The composition of the participants was as follows: NGO people $(6-25 \%)$, local government staff $(5-10 \%)$, local parliament members $(4-10 \%)$, scholars $(10-12 \%)$, students $(8-10 \%)$, TVRI and RRI staff (14-18\%), cultural observers $(10-12 \%)$, artists $(10-15 \%)$, religious leaders $(5-$ $9 \%$ ), media people $(5-6 \%)$, business people $(5-6 \%)$, others $(4-5 \%)$. They came from the 10 host cities as well as from 64 surrounding cities.

Not surprisingly, various issues uncovered during the pre-assessments re-emerged as core issues in the seminar rounds. Three factors could possibly account for the consistency of issues in the two phases. First, of course, was the possible fact that the advocacy and research team managed to capture the most significant issues covering what broadcasting meant to local people during the pre-assessment round. Second, in the pre-assessment round, the team had already met with key figures who later on turned out to be the more enthusiastic participants in the seminars when reformulating their opinions and criticisms. Third, although the international speakers tried to comprehensively describe aspects of public broadcasting in their home countries, the participants seemed to be more interested in or wanted to limit the discussions to the problems of TVRI and RRI. 
The local TVRI and RRI producers seemed to appreciate the opportunity to showcase their best public-oriented programming. Most thought that their programs already incorporated the principles put forward in public broadcasting arguments. Virtually all producers brought in a talk show program, a news or feature program, and/or a traditional performance. After underlining the everyday production obstacles, such as the very limited budgets, they usually tried to defend their programs as meeting the public needs.

The NGO activists and academics raised a lot of questions and criticisms towards RRI and TVRI staff. They particularly questioned the insufficient attention that TVRI and RRI had shown over the years for issues such as ethnic minorities and marginalized people. They pointed to issues such as poor people being forcefully relocated from their land and property in the name of 'development' or 'public interest', the problems of street children, the unemployed, issues that rarely make it on TV or radio. They were also disappointed with the disappearance of instructional programs that are felt to be helpful for farmers. Some NGO activists related stories about TVRI and RRI staff who only cared about how much money the NGO can contribute to the production, without any consideration whatsoever for the benefits the program can bring to the people. The academics expressed their concerns about the lack of audience research conducted by TVRI or RRI.

Representatives of local governments could not hide their ambition to ensure that the local governments regain unlimited access to the local TVRIs and RRIs. They argued that if local stations are to be supported by local government budgets, the latter should serve the interests of the local government. Not surprisingly, the NGO people and academics rejected their idea. The international speakers explained that in some countries a TV or radio council should first be established so that all segments of stakeholders, including the local government, can have equal access to public broadcasting.

Suggestions were voiced that the local participants needed to establish a forum bringing together stakeholders to think about TVRI and RRI issues and to help find solutions to the problems. This idea to establish a stakeholders forum in an effort to rebuild local TVRIs and RRIs got support from local parliament members. Two moments of implementation were suggested; waiting for a clear, legal framework, that is, the finalization of the legislation process of the Broadcasting Bill. Some others, such as the legislators in North Sulawesi, South Sulawesi, Bali, East Java, and Yogyakarta, did not want to wait that long and emphasized the fact that the local legislators together with the local government have the right to establish such a forum on the basis of the local autonomy 
law. If necessary, the forum could later be adjusted to the new Broadcasting Law.

Finally, at the end of the seminar, a plenary session brought about the results of the discussion on the needs assessment. In summary, five important points were agreed upon:

(1) The participants needed to take concrete action;

(2) The initiators of the discourse and program were expected to set up a comprehensive strategy. Only by developing a solid strategy could one move forward quickly in order to seize the opportunity and maintain the momentum;

(3) Overall, it should be clearly stated which stakeholders can interact harmoniously with TVRI and RRI, within which kinds of networks local groups are allowed to interact, and through which coordination mechanisms;

(4) Immediate steps should include the development of programs involving various stakeholders; the broadcast townhall meeting is one of the most plausible programs to implement as a pilot project;

(5) The development and publication of a guidance book for public and community broadcasting, compiling experiences from other countries, the Indonesian experience, and the concepts and ideas developed during the seminars, was felt to be an urgent necessity.

When formulating these recommendations, some suggestions were made on the term to be used for the stakeholders' forum. One widely preferred term is LCF (Local Consultative Forum).

\section{Local consultative forums and local programs}

After the seminar series, the advocacy and research team kept arranging meetings among the local representatives. So far 36 discussions have been held with the stakeholders of public and community broadcasting in ten cities.

Besides the meetings, the team also facilitated the production of TV and radio programs involving local constituents as recommended in the workshops. Due to the limited funding, not all programs jointly produced by the local TVRI and RRI with the initial LCFs can follow the townhall meeting format. A substantial portion of the joint production costs were made available by the United States Agency for International Development (USAID) disbursed through IFES (International Foundation for Election System). At times, in a few regions, some additional funds were made available from other NGOs involved in LCF, especially when the topic of the program - usually a talk show - was closely 
related to the field of activities of those NGOs. Of the 309 programs aired on TVRI and RRI since November 2001 to September 2002, only 30 per cent was produced in the townhall meeting version. Here, by the townhall meeting format we refer to the following characteristics:

(1) Dialogue involving representatives of stakeholders in that area (any combination of NGO activists, academics, TVRI and RRI staff members, local government officials, local parliament members, business people, artists, cultural observers, etc.);

(2) In addition to the stakeholders, 30 to 50 residents with various backgrounds are to be invited to the studio; during the show they are encouraged to be active participants, giving comments, criticisms, suggestions, etc.;

(3) The show was broadcast live and open to call-ins. Another format for the joint productions between LCF and local TVRI and RRI is the interactive dialogue. Usually there was no audience in the studio except the speakers and moderator who would hold a discussion on a certain topic which took up one fourth of the total time, while the rest was open to audience participation through call-ins.

Along with the joint production activities, some initial LCFs became more solid. Six of them are already officially launched, for example, the Yogyakarta Society for Public Broadcasting (Yogyakarta), the East Java Forum for Public Broadcasting (Surabaya), the Media Forum for Brotherhood (Manado), the Makassar Local Consultative Forum (Makassar), the Bali Television Society (Denpasar), and 'Balarea' in Bandung ('Balarea' also means brotherhood or togetherness). Beyond the ten original cities, some are attempting to establish their own LCF, including Banjarmasin, Mataram, Banten, and Banda Aceh. In general, whether an LCF in a city makes progress depends on: (1) the creativity of the LCF members in that area; (2) the cooperativeness and creativity of the manager and staff of TVRI and RRI; (3) the strength of support from local parliament members and local government staff: (4) the funding from external relevant donors to bear the joint production costs.

Local RRI staff members have become more and more cooperative. They have also been flexible in the discussion about the joint production costs. It is now clear that from its board of directors in Jakarta to the 52 branch-heads across Indonesia, the management of RRI have already agreed that RRI can no longer keep a paternalistic attitude. At the end of 2002, RRI conducted its first national audience research, which was designed especially to address the characters and performance indicators of a public radio. 
Local TVRI managers in Yogyakarta, Surabaya, Manado, Papua, Samarinda, Denpasar, Makassar, and Medan were among the few who were open to dialogue with LCFs. They were, to a certain extent, willing to develop joint programs with the LCFs and understand that the joint production costs should be covered together. In the other cities, the LCFs tended to see the TVRI high-ranking officials as not being cooperative or even holding on to a paternalistic attitude.

With the contribution of no less than 153 LCF members, the Communication Department, University of Indonesia, published the first guidance book on public and community broadcasting. Copies of the book have been distributed to all the members of the parliament commission and the special committee dealing with broadcasting. The ideas and models of public and community broadcasting and the constituents to support them are in place. However, the LCFs are still in an embryonic phase. Lots of backstopping is still needed to make them self-sustainable.

\section{What Further?}

This kind of action research becomes significant in the context of broadcasting in Indonesia because it combines research and advocacy. It demonstrates that the paradigm of working with the people can successfully change the societal hierarchy of issues. This research and advocacy have been developed through listening to the local voices. Starting from the pre-assessment rounds, the needs-assessment workshops, the local production and the evaluation, the locals always take the lead with the researchers providing active facilitation.

In general, local representatives in Indonesia wholeheartedly welcomed the discourse on public broadcasting although the motives varied from group to group. There were two main reasons why the support for public broadcasting was rather strong. First, they needed a broadcasting medium accessible to many people and, more importantly, one that could be used to express opinions, needs, and preferences of the common people. The emphasis is on the goal to turn public broadcasting into a forum to accelerate the process of democratization in Indonesia. Secondly, in the context of presenting identities, traditional arts, and local cultures the local representatives expressed that active participation of the local public is a prerequisite. The demand is apparently based on the assumption that only people living in the local tradition and culture can appropriately and accurately reproduce the traditional arts and other cultural artifacts on the media.

As a concrete follow-up, the various stakeholders in the local public expressed the need for a forum allowing them to be actively involved in 
establishing public and community broadcasting in their area. This forum will become the channel for the local community to work with RRI and TVRI to ensure that these stations serve the interests of the local public. Only through such forums can the local stakeholders provide a rationale that TVRI and RRI are public broadcasters with programming that suits the needs and preferences of the local public and thus deserves public funding. There is no doubt that to most people RRI and TVRI are the logical choice to initiate public broadcasting. However, there is no guarantee that locals will always support these two former state broadcasting institutions to serve their needs because there has already been a warning that new institutions will be established to replace RRI and TVRI locally should they not perform satisfactorily on the public broadcasting indicators.

So far, the forums that turned into LCFs (Local Consultative Forums) have established excellent working relations with virtually all RRI stations in their respective regions but they only succeeded in a few TVRI stations. Therefore many local representatives hold the perception that RRI no longer adopts a paternalistic attitude while TVRI seems unable to rid itself of its 'greater than thou' attitude.

On November 28, 2002, amid mounting pressures from commercial TV stations, the Parliament passed the Broadcasting Bill into act with a full recognition of public and community broadcasting. The details of this new Act will be developed into lower-level regulations and certainly need to be anticipated by the advocacy groups together with LCFs and local people. In line with this development, at least three factors may still hamper the continuation of an LCF. First, the position of the public vis-à-vis community and public broadcasting is unclear because the Broadcasting Law does not address it in sufficient details. Secondly, TVRI stations in many areas have not demonstrated their acceptance of the idea of a local consultative group, nor have they shown willingness to work closely with local groups in production. Thirdly, there is a lack of funding to support existing and new LCFs in their initial stage.

Should the regulations and implementation of the Broadcasting Law incorporate the idea of public involvement in the broadcasting operation through a (formal) supervisory board, the LCF can still play the informal role of the 'Friends of Community and Public Broadcasting'. The LCF can also serve as a breeding ground for candidates for that supervisory board since participation in this board is indicative of one's concern with and interest in public and community broadcasting. In the meantime, some LCFs have involved themselves in media literacy programs and in assessing the drafting process of the new Broadcasting Law as well as the new Election Law. In short, the LCFs have served the function of advocacy for broadcasting and democracy issues. Whether 
they will be useful in the long run, in terms of developing public broadcasting in Indonesia, remains to be seen. At least they are playing a quite significant role in guiding Indonesia through this transitional phase that could easily lure the society from an authoritarian system into a marketdriven system.

In any case, according to the most recent data, there are currently at least 15 local television stations. They joined two associations: Asosiasi Televisi Publik dan Komunitas Indonesia (Indonesian Public and Community Television Association), which was established in Balikpapan, 28 April 2002 and Asosiasi Televisi Lokal (Local Television Association), which was established in Bali, 26 July 2002. Meanwhile, more than 100 community radios have been recorded and most joined the Jaringan Radio Komunitas Indonesia (Indonesian Community Radio Network) established on 15 May 2002. Prior to that, there was Jaringan Radio Komunitas Yogyakarta (Yogyakarta Community Radio Network) with 52 radio members and Jaringan Radio Komunitas Jawa Barat (West Java Community Radio Network) with 23 radio members.

\section{Note}

1. These interviews, discussions, and observations were recorded by the researchers.

\section{References}

Byrant, C. and White, L.G. (1982). Managing development in the Third World. Boulder, CO: Westview Press.

Chan, J. M. and Ma, E. K. W. (1996). Asian television: Global trends and local processes. Gazette, 58(1), 45-60.

Cohen, J. and Uphoff, N. T. (1980). Participation's place in rural development: Seeking clarity through specificity. World Development, 8(2), 213-235.

d'Haenens, L., Gazali, E., and Verelst, C. (1999). Indonesian television news making before and after Suharto. Gazette, 61(2), 127-152.

d'Haenens, L., Verelst, C., and Gazali, E. (2000). In search of quality measures for news programming in Indonesian television: If the program makers had their say. In D. French and M. Richards (Eds.), Television in contemporary Asia (pp. 197232). New Delhi: Sage.

d'Haenens, L. and Saeys, F. (Eds.). (2001). Western broadcasting at the dawn of the $21^{\text {st }}$ century. Berlin: Mouton de Gruyter.

Gazali, E. (Ed.). (2002). Penyiaran alternatif tapi mutlak: Sebuah acuan tentang penyiaran publik and komunitas [A necessary alternative: A guide to public and community broadcasting]. Jakarta: Jurusan Ilmu Komunikasi FISIP UI.

Hidayat, N. D., Gazali, E., Suwardi, H., and Ishadi, S. K. (Eds.). (2000). Pers dalam Revolusi Mei: Runtuhnya sebuah hegemoni [The press during the May Revolution: The fall of a hegemony]. Jakarta: Gramedia.

Hill, D. and Sen, K. (2000). Media, culture and politics in Indonesia. Oxford: Oxford University Press. 
Hollander, E., Stappers, J., and Jankowski, N. (2002). Community media and community communication. In N. W. Jankowski and O. Prehn (Eds.), Community media in the information age: Prospectives and prospects (pp. 22-23). Cresskill, NJ: Hampton Press.

Jankowski, N. W. (2002). The conceptual contours of community media. In Jankowski, N. W. and Prehn, O. (Eds.), Community media in the information age: Prospectives and prospects (pp. 7-8). Cresskill, NJ: Hampton Press. 